\title{
12. Indigenous Empowerment in Land Management
}

\author{
Mark Chmielewski
}

I manage the Indigenous Landholders Service(ILS), a program within the Western Australian Department of Agriculture and Food. Though the department has been in existence for over 100 years, the ILS has only existed for 13 years. We work with Aboriginal landholders and the approach that we take is to primarily employ Indigenous Western Australians from the state's remote communities, its pastoral industry, its agricultural industry and from within the state government itself. The current team is solid and has essentially been together for five years - a great retention rate.

\section{Origins of the ILS}

The Indigenous Landholders Service started 13 years ago at Noonkanbah pastoral station in the Kimberley region of Western Australia. Around 350 people live on Noonkanbah, which raises cattle. In 1998 the station's herd suffered a severe tuberculosis outbreak, provoking a visit from the Western Australian Department of Agriculture's Tuberculosis Program. Unfortunately, such was the severity of the outbreak that one of our officers had to destroy 1200 head of cattle. The loss took away the Noonkanbah community's ability to create employment and training — its ability to pay bills and wean itself off welfare.

Facing this crisis, Noonkanbah community leaders asked the visiting officer, 'What are we going to do now? How are we going to pay our wages? How are we going to employ our people?' The officer thought about this, and promptly went beyond his scope. He was there to address the tuberculosis outbreak - not the needs of the community. And yet, the officer sat down with the community and together they developed a pastoral management plan. He recognised that there were some inherent weaknesses and governance shortcomings in the way Noonkanbah was being run. Consequently, there were a range of negative issues affecting the local residents. So, from this meeting between that particular officer and the community grew the Indigenous Landholders Service.

From those humble beginnings it has grown to become an incredible success. At that point Noonkanbah was a couple of hundred thousand dollars in debt. Today they are still receiving an extension service, but they are now putting 
close to \$2 million back into the community. Importantly, Noonkanbah is employing people in remote Australia. There are young, primarily Indigenous, people coming up through the education system who want to go and work on that property that may have otherwise ended up on the welfare cycle. In that sense Noonkanbah is providing an opportunity for a bright future for young Indigenous people in the Kimberley, and an opportunity for those who have already fallen into welfare dependence to lift themselves out of it.

Beginning at Noonkanbah 10 years ago, the ILS now encompasses 77 properties. There are still more properties out there needing access to our services, but we simply cannot assist them because of a lack of government resources. And yet, we have still been able to enact what is nothing less than a revolution in service delivery.

Unfortunately Western Australia has a history of what I call 'unserviced' landholders. While repatriated soldier settlers returning to the state after World War I and World War II were given low interest rate loans and Department of Agriculture support to accompany their land allocation (business management, cropping, machinery and animal husbandry advice), no such support was given to the next wave of repatriation - to Aboriginal people in the 1970s, 1980s and 1990s, who were allocated pastoral stations and farms to go to. Consequently, 30 years after these first waves of Indigenous repatriation, the ILS is trying to redress some of the problems that have accumulated in the ensuing decades.

\section{Approach of the ILS}

The approach of the ILS is a holistic one: focusing on people and developing relationships between them. Everything else fits around this method. When we go to properties, we have a couple of major themes to help us succeed. One is an emphasis on the development of skills and knowledge within a community, so that they can make informed decisions regarding their own governance. This can be achieved through training.

Crucial to this is the desire for employment, and the opportunity to create employment. To do this we sit down with the community or corporation in question and work through what it is they want to achieve out of the property. There is no one answer to this question, but essentially it is about designing and implementing a communal goal for the landholders.

For this to be successful, a long-term approach must be undertaken - we are consistently trying to convince government to look beyond the election 
cycle; that a three-year turnaround on this issue is unrealistic. This is about generational change. The ILS is also beneficial to the Department of Agriculture because it increases property productivity.

We are held accountable for the public dollars that we spend in each ILS project and, as well as paying for independent evaluation and validation of our work, we also conduct internal assessments from within the Department of Agriculture. These come in the form of quarterly reviews, bi-annual reviews, annual reviews and two-year reviews. Though this process sounds very bureaucratic, we do not lose sight of the fact that we employ a grass roots approach that runs parallel to a strong evaluation and justification purpose.

We are an invitation-based organisation. As a consequence, when a corporation says to us, 'can you come and help us with our land, we are struggling', we sit down and we attempt to understand the people; we try to understand their story. We identify what skills they have, before starting to develop a property plan. Then we assist with governance because governance and business support are mutually beneficial. If you have one without the other a lopsided equation can eventuate, and this can hamper the betterment of the community in question.

Essentially though, the success of an ILS-serviced property depends on us being able to initiate developmental plans and structure training, identify the weaknesses and strengths, then assist the corporation to move above and beyond where it wants to go. We have our partners in this. Though the program started off as a collaboration between the WA Department of Agriculture and the communities, over time it has developed to the point where it has become a cross-government, holistic service and other government agencies are now climbing on board to assist in the implementation of their activities as well.

The Indigenous Land Corporation, an independent statutory authority of the Commonwealth government, is a funding partner of the ILS program. The communities themselves are obviously the major stakeholders, and then a whole range of agencies further down the tier are also involved in the work that we do. Because of the agencies and activities that are now involved, coordination is critical - there is nothing worse for a community than to see a stream of $4 \times 4 \mathrm{~s}$ come in and out over the course of a week, with each agency wanting to deliver their own outcomes. Because of this, through a process of evolution, the work of the ILS has become structured around a system of property management so we can assist the other agencies involved to deliver an effective service. 
Putting Citizens First

\section{Impact and outcomes}

The 77 properties we service provide land to 4000 people, and it is their lives that are most impacted by the management and use of the land on which live on. While these people may not all get a job thanks to the ILS, they have certainly been given training opportunities as a consequence of our involvement. Milijitty and Lamboo are two successful examples of pastoral properties that have benefited from their relationship with the ILS, and where the custodians now exhibit a real sense of pride in their station and community.

Economic outcomes are the most significant impact the ILS has on the properties it serves. I have highlighted Noonkanbah as a successful example earlier in this chapter, but there are many other, similar, case studies. Noonkanbah's neighbouring properties are an example. They are also Aboriginal communities and they also have many people associated with their land. These properties have been able to replicate what their next-door neighbour, Noonkanbah, has achieved: they are now starting to implement their own goals and their own objectives - processes we are helping to facilitate.

There are also regional implications of this scheme. Often, when an Indigenousrun property falls into debt, there are negative flow-on effects for the region as a whole. We have come to properties, for example, that haven't paid bills, and the local helicopter pilots or the livestock agents or the truckers have told us, 'we're not touching that property, we've been there, we've got a $\$ 7000$ bill, they haven't paid it. Forget about it'. Such a situation is not good for anybody. But, what we have equally found is that, through the ILS facilitation process, once these properties start developing their business and generating some cash, they can repay that debt and repay some of that lost faith. Consequently, once the community has won the trust of mainstream service providers, the commercial world can come onboard as a mechanism for reconciliation.

There are truckers, for example, now actively engaged in transporting cattle from Aboriginal-owned properties. There are helicopter pilots now recognising and acknowledging that these properties have instituted strong corporate governance, and so they are once more servicing them. In this way, the regional roll out and fan-out effect is considerable.

A number of the properties that we worked with have achieved self-sufficiency in a short period of time, which is something that brings with it its own set of challenges. From not having any money in the bank, these properties now have to understand the varying responsibilities associated with having $\$ 10,000$, $\$ 100,000$ or even $\$ 1,000,000$ in the bank. In addition to becoming financially literate, these properties have to also deal with the challenges of creating a business in an environment where basic literacy and numeracy is still a major 
issue, and to assist in implementing structures that protect the investment of their corporation in a trusting way, without it being unfairly exploited by outsiders.

As the properties have developed, 55 full-time and 83 part-time jobs have been created. While these figures may not sound world-beating, each one represents a person who has come off welfare and who is now involved in their own businesses, on their own land.

Take the case of Robin, a man from Halls Creek. Robin grew up in a humpy on the edge of town with no electricity or running water - a very different upbringing to most Australians. He used to walk a couple of kilometres to school - when he wanted to attend. There was no real incentive for him to go to school in Halls Creek. He started life much like his peers and by the time he had reached early adulthood, Robin was abusing alcohol and engaging in antisocial behavior.

Fortunately, at this stage, Robin's father sent him to agricultural college in Katherine and, while he didn't graduate before returning to Halls Creek, he gained enough knowledge in pastoral business for us to engage with him and convince him to apply his skills in his home community.

Robin doesn't drink anymore. He's since completed his diploma in agricultural science and become a leader in his community. He still lives in Halls Creek, from where he runs a pastoral station and is the chair of his corporation. He is an example of an Indigenous Australian who has taken a land asset that was depreciating in value and restructured it into something more positive (and lucrative). Now all his nephews are standing around looking at Robin saying, 'I want to be just like my uncle', they are lining up to go to school. These are little steps, but they prove we making progress.

And, while such outcomes are heartening, we must equally recognise that agriculture is not necessarily the professional pinnacle for all Indigenous Australians living in remote areas. Often it is a just a starting point. John, a former shearer from Albany in southern Western Australia, is a good example. Much like Robin, John dropped out of high school and got into the welfare cycle. But then he became involved with some of the properties we work with, where he realised he enjoyed - and was very good at — shearing. He was shearing about 150 sheep per day, which is impressive for a first-year shearer. In addition to this skill, John developed an impressive work ethic and, after starting as a trainee, he was soon accepted into a commercial shearing contracting team.

Having acquired that work ethnic through agricultural experience, John, who is only 23, has transferred it to Western Australia's mines, where he now drives heavy machinery. He is earning good money, and is leading a good life. 
Like Robin, he has become a role model for young people in his community; a community he wants to give back to. Unlike Robin though, John's trajectory shows Indigenous kids from the bush that they don't necessarily have to end up in agriculture. His story is one of professional transformation, and the ILS can assist in that process.

\section{Cultural outcomes}

Cultural awareness is obviously important in what we do, and critical to the success of the ILS. Near the town of Meekatharra, in the middle of Western Australia, there used to be a pastoral station. The WA Department of Agriculture thought it was running smoothly until the day we decided to see for ourselves. Because Aboriginal people tend not to attend field days, they generally don't think to pick up the phone and call the department when they have a problem. So, unless we visit these properties for ourselves, a large group of people don't have access to the department's services. When we arrived at the property, the management said that they did in fact have problems. We conducted an inspection of the property and confirmed that these problems were so severe that they were putting the community at risk of losing their property altogether.

This community didn't want to run a property, but, rather, it wanted to maintain it for cultural reasons. They were from that country; they were born there; they had stories that were attached to that country. So they wanted to retain it in order to maintain their sites, continue their law and continue to teach their children about their culture. Once we understood this, representatives of the ILS met with custodians of the property to devise a model whereby management of the property was outsourced, but the community could still maintain it for cultural purposes. This was achieved through sub-leasing.

Under this arrangement the property's next-door neighbor subleases the land, improves the infrastructure and runs his cattle on it. The contract stipulates, however, that the landholders can have access to the country whenever they need to in order to maintain their cultural sites or educate their people. Equally, they can stay at the homestead during these occasions and have first priority of any employment and training outcomes attached to the pastoral use of the property. It is thus a win/win situation. It is understood that the men of that particular corporation had given up using the land for agriculture, but their women convinced them to find a way of maintaining it. As a result we have a situation where, in 15 years' time the land is still there for the grandchildren to take over the lease, should they ever wish to do so.

This example also highlights the benefits of taking the time to visit a community and ask them if they have any problems. Often, when departments use the word 
'engagement', what they mean is engagement with a particular agenda set by the community. But, at the ILS, we have learned that when you sit down with a community, the issues are often so much broader than initially anticipated and require meaningful, two-way engagement. Not a lot of departments put the time, effort and energy into sitting down and understanding the needs of communities - something that can take a long time.

When it comes to Indigenous-government engagement, there remains a significant level of mistrust. Consequently, these meetings can often take hours before the talking actually starts. It's unrealistic to expect people to declare their issues in the first couple of meetings; instead we have to tease them out and use different methods to establish exactly what their issues are.

\section{The challenge of gaining executive and institutional support}

The ILS is not without its detractors. While the key trigger for the creation of the service was the development of a relationship between a government employee and a community, the scheme's development and sustained success has depended upon support at a higher level: within management, within the executive, from the department's head and from the WA minister for agriculture. As an innovative approach to Indigenous land management, this has not always been straightforward.

The, sometimes difficult, process has involved making such people and institutions aware of the innovation at work, and in so doing finding a champion to drive the process and keep a particular project going. For a long time, what we do flew under the radar in the corridors of power in Perth, but there was only so long before the success of the program became known, even to those who, for whatever reason, may not want to be convinced of its virtues.

And while the ILS has not been entirely endorsed yet - the WA Department of Agriculture is conservative - the program's success to date has been such that it continues to shift peoples' attitudes to this issue, meaning we continue to gain champions for our cause.

\section{A national and international role model}

From its simple beginnings at Noonkanbah station, the ILS has grown to become a model of success to be emulated across Australia and the world. Not only has the United Nations recognised the work that we do, we are two-time WA premier's 
award winners for excellence in public service and also previous winners of the prime minister's award for excellence in public service. Interested parties from African nations have visited Western Australia to observe our activities, and the South African Government, in particular, is trying to implement a similar model in that country.

I am not aware of another service in Australia that delivers such a holistic approach; that sits down and breaks the mould of accepting what can and cannot be done. When liaising with other agencies we often get told, 'we'd love to help, but what you're doing isn't part of our agenda.' The ILS is about breaking this mentality by being innovative, entrepreneurial and committed in order to find ways to solve problems that have long been deemed too difficult. 